\title{
Experimental and theoretical investigations on the high-electron donor character of pyrido-annelated $\mathbf{N}$-heterocyclic carbenes
}

\author{
Michael Nonnenmacher ${ }^{1}$, Dominik M. Buck ${ }^{2}$ and Doris Kunz ${ }^{* 1,2}$
}

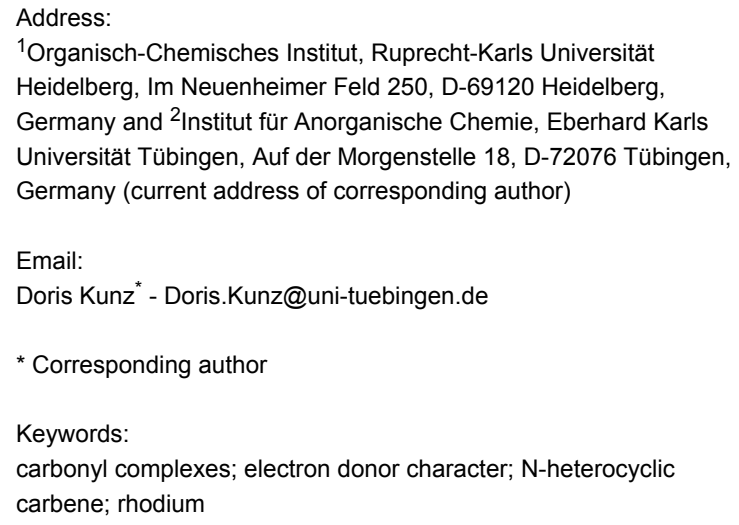

Beilstein J. Org. Chem. 2016, 12, 1884-1896. doi:10.3762/bjoc.12.178

Received: 17 May 2016

Accepted: 04 August 2016

Published: 23 August 2016

This article is part of the Thematic Series "Organometallic chemistry". In memoriam Professor Peter Hofmann.

Guest Editor: B. F. Straub

(c) 2016 Nonnenmacher et al.; licensee Beilstein-Institut. License and terms: see end of document.

\begin{abstract}
$\mathrm{Rh}(\mathrm{CO})_{2} \mathrm{Cl}(\mathrm{NHC})$ complexes of dipyrido-annelated $\mathrm{N}$-heterocyclic carbenes were prepared. From the $\mathrm{C}-\mathrm{H}$ coupling constant of the respective imidazolium salts and the $\mathrm{N}-\mathrm{C}-\mathrm{N}$ angle of the $\mathrm{N}$-heterocyclic carbene (NHC), a weaker $\sigma$-donor character than that of typical unsaturated NHCs is expected. However, the IR stretching frequencies of their $\mathrm{Rh}(\mathrm{CO})_{2} \mathrm{Cl}$ complexes suggest an electrondonor character even stronger than that of saturated NHCs. We ascribe this to the extremely weak $\pi$-acceptor character of the dipyrido-annelated NHCs caused by the conjugated $14 \pi \mathrm{e}^{-}$system that thus allows for an enhanced $\mathrm{Rh}-\mathrm{CO}$ backbonding. This extremely low $\pi$-acceptor ability is also corroborated by the ${ }^{77} \mathrm{Se}$ NMR chemical shift of $-55.8 \mathrm{ppm}$ for the respective selenourea, the lowest value ever measured for imidazole derived selenoureas. DFT-calculations of the free carbene confirm the low $\sigma$-donor character by the fact that the $\sigma$-orbital of the carbene is the HOMO- 1 that lies $0.58 \mathrm{eV}$ below the HOMO which is located at the $\pi$-system. Natural population analysis reveals the lowest occupation of the $\mathrm{p}_{\pi}$-orbital for the saturated carbene carbon atom and the highest for the pyrido-annelated carbene. Going from the free carbene to the $\mathrm{Rh}(\mathrm{CO})_{2} \mathrm{Cl}(\mathrm{NHC})$ complexes, the increase in occupancy of the complete $\pi$-system of the carbene ligand upon coordination is lowest for the pyrido-annelated carbene and highest for the saturated carbene.
\end{abstract}

\section{Introduction}

$\mathrm{N}-$ Heterocyclic carbenes form a ligand class that is typically characterized by a strong $\sigma$-donor and a weak or even negligible $\pi$-acceptor effect [1-3], although Meyer has shown pronounced $\pi$-acceptor ability in $\mathrm{Cu}$ complexes [4-6]. In recent years many varieties of N-heterocyclic carbenes have been synthesized $[7,8]$, focusing mainly on a strong $\sigma$-donor character, for example by increasing the ring-size [9-15], substituting one nitrogen atom by carbon $[16,17]$ or using diamido backbones 
$[18,19]$ and only rarely on enhancing the $\pi$-donor character by using $\pi$-electron donating backbones [20]. Many efforts have been made to determine and compare the donor abilities of N-heterocyclic carbenes including DFT calculations [2-6,2124], among which are the most prominent examples: the Tolman-parameter [25-28], the ${ }^{13} \mathrm{C}$ NMR chemical shift of special $\mathrm{Pd}(\mathrm{NHC})_{2}$ complexes [29,30], and electrochemical properties [31-33] (see [34,35] for reviews). In all these cases, only the overall donor-abilities of the NHC ligand are obtained. In the case of the Tolman parameter, not only the electronic properties of the carbene influence the $\mathrm{CO}$ stretching modes, but also steric effects and the coupling of stretching modes. The latter two drawbacks have recently been overcome by calculating the metal-ligand electronic parameter (MLEP) [36]. Separating the influence of the $\sigma$-donor and $\pi$-acceptor abilities was limited to determining the overall donor character and taking into account the $\sigma$-donor character. The latter is dependant on the s-character of the $\sigma$-orbital and thus can be obtained directly from the ${ }^{1} J_{\mathrm{CH}}$ coupling constant of the imidazolium salt [37-39] (which can be regarded as the $\mathrm{H}^{+}$complex of the carbene and therefore $\pi$-influences are avoided) or by the $\mathrm{N}-\mathrm{C}-\mathrm{N}$ angle at the carbene [40], which also correlates with the ${ }^{13} \mathrm{C}$ NMR chemical shift [41]. In 2013, Ganter presented the ${ }^{77} \mathrm{Se}$ NMR chemical shift of the respective selenoureas as a suitable probe to determine directly the $\pi$-influence of the carbene $[42,43]$, as the paramagnetic shift tensor has the largest influence on the ${ }^{77} \mathrm{Se}$ NMR chemical shift. This method is so far redundant [44] to the method of determining the ${ }^{31} \mathrm{P}$ NMR chemical shifts of the respective NHC-phosphinidene adducts $[45,46]$.

For some years we have worked with pyrido-annelated $\mathrm{N}$-heterocyclic carbenes, an NHC class that was introduced by Weiss and co-workers (Figure 1) [39,47]. They pointed out the unusual high s-character of that carbene $\sigma$-orbital by a ${ }^{1} J_{\mathrm{CH}}$ coupling constant of $232.6 \mathrm{~Hz}$, which corresponds to a hybridization of only $\mathrm{sp}^{1.15}$. Although they had prepared the respective selenourea, the ${ }^{77}$ Se NMR chemical shift was not reported $[39,47,48]$. We showed that the tert-butyl substituted dipyridocarbene dipiy ${ }^{\mathrm{tBu}}$ exhibits an unusual high thermal stability and proofed the alternating bond lengths in the conjugated $\pi$-system of this carbene (similar to heptafulvalene) as well as the very low $\mathrm{N}-\mathrm{C}-\mathrm{N}$ angle by $\mathrm{X}$-ray structure analysis [41]. Weiss proposed this carbene to have a "built-in umpolung" [39] ability which means that there could be a participation of the dicationic bisylidene resonance form as it is usually described for carbodiphosphoranes [49] and carbodicarbenes [50,51], in which the carbon atom has a formal oxidation state of \pm 0 (Figure 1) [52-54]. Earlier, we had prepared their tungsten and chromium carbonyl complexes, but could not find deviations of the $\mathrm{CO}$ stretching frequencies from those of analogous $\mathrm{NHC}$ complexes [55]. As this might be due to the distribution of the effect on five carbonyl ligands, we now prepared the $\left[\mathrm{Rh}(\mathrm{CO})_{2} \mathrm{Cl}\right.$ (dipiy)] complex to obtain a more sensitive probe. In the following we will provide the experimental evidence that dipyrido-annelated carbenes are indeed not only weak $\sigma$-donors but also the weakest $\pi$-accepting carbenes derived from imidazole so far. This overcompensates even the lower $\sigma$-donor character, so that their overall electron-donating ability lies in between that of acyclic diaminocarbenes and saturated NHCs.

\section{Results and Discussion \\ Synthesis of the rhodium $\mathrm{CO}$ and ${ }^{13} \mathrm{CO}$ complexes $\mathbf{2 a}$ and $\mathbf{2} \mathbf{b}$}

We generated the desired carbonyl complexes $\mathbf{2 a}$ and $\mathbf{2 b}$ from the respective COD complex 1 [56] by ligand exchange under a ${ }^{13} \mathrm{CO}$ atmosphere of 6 bar in $\mathrm{CD}_{2} \mathrm{Cl}_{2}$ in a pressure-NMR tube according to Scheme 1 .

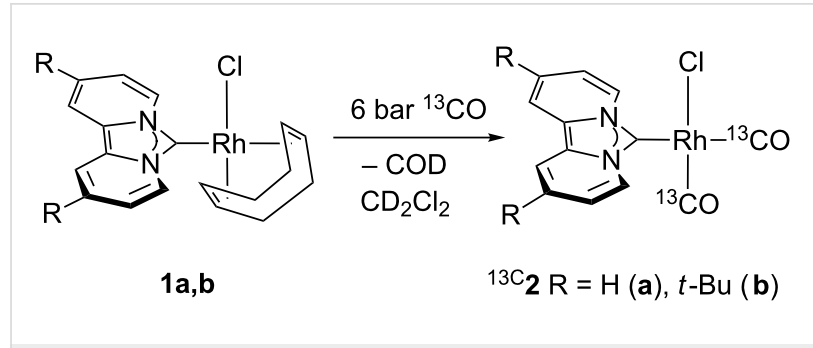

Scheme 1: Preparation of the ${ }^{13} \mathrm{CO}$ substituted rhodium complexes 2 bearing the dipyrido-annelated carbenes dipiy (a) and dipiy ${ }^{\mathrm{tBu}}(\mathbf{b})$.

At first, a precipitate forms which is redissolved shortly after and a color change of the solution from light yellow to greenish
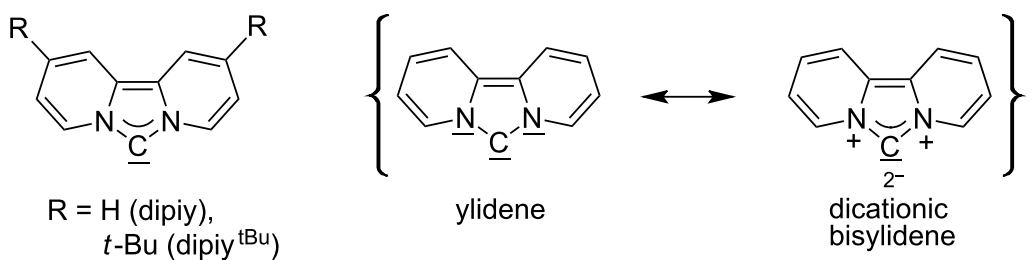

Figure 1: Left: resonance hybrid of the dipyrido carbenes dipiy and dipiy ${ }^{\mathrm{tBu}}$. Right: two canonical forms of the dipyridocarbene according to Weiss and co-workers. 
yellow occurs. The ${ }^{1} \mathrm{H}$ NMR spectrum confirms full conversion and release of the COD ligand. Due to a fast exchange with the ${ }^{13} \mathrm{CO}$ atmosphere, the respective ${ }^{13} \mathrm{C}$ NMR carbonyl signals were not detected. Therefore, we measured the ${ }^{13} \mathrm{C}\left\{{ }^{1} \mathrm{H}\right\}$ NMR spectra at $-30{ }^{\circ} \mathrm{C}$. The doublet at $185.9 \mathrm{ppm}$ with a ${ }^{1} J_{\mathrm{RhC}}$ coupling constant of $53.6 \mathrm{~Hz}$ refers to one ${ }^{13} \mathrm{CO}$ ligand, while a broad peak at $183.0 \mathrm{ppm}$ indicates fast exchange of the second ${ }^{13} \mathrm{CO}$ ligand with non-coordinated ${ }^{13} \mathrm{CO}$ (Figure 2). Neither cooling down the sample to $-50{ }^{\circ} \mathrm{C}$ nor the release of the ${ }^{13} \mathrm{CO}$ pressure to 1 bar changed the spectrum qualitatively. The sample was then shaken in an open atmosphere of nitrogen to remove the non-coordinated ${ }^{13} \mathrm{CO}$. This led to a substantial decrease of the intensity of the broad peak, but only after three freeze-pump-thaw cycles to fully remove residual ${ }^{13} \mathrm{CO}$ the former broad signal turned into a sharp doublet of doublets at $183.2 \mathrm{ppm}$ with a ${ }^{1} J_{\mathrm{RhC}}$ coupling of $72.8 \mathrm{~Hz}$ and a ${ }^{2} J_{\mathrm{CC}}$ coupling to the second ${ }^{13} \mathrm{CO}$ ligand of $6.1 \mathrm{~Hz}$. Consequently, the former doublet at $186.3 \mathrm{ppm}$ for the second ${ }^{13} \mathrm{CO}$ ligand appears now as a doublet of doublets $\left({ }^{1} J_{\mathrm{RhC}}=54.5 \mathrm{~Hz}\right.$ and ${ }^{2} J_{\mathrm{CC}}=6.1 \mathrm{~Hz}$ ).

A comparison of the ${ }^{1} J_{\mathrm{RhC}}$ coupling constants with those of $c$ isand trans-CO Rh-NHC complexes bearing an additional $\mathrm{P}$ donor reveals a smaller ${ }^{1} J_{\mathrm{RhC}}$ coupling constant for the trans$\mathrm{CO}$ ligand and a larger coupling constant for the cis-CO ligand (relative to the NHC ligand) [57]. This trend is also observed for the ${ }^{1} J_{\mathrm{RhC}}$ coupling constants of carbonyl complexes with phosphine ligands [58,59]. Consequently, the signal at $186.3 \mathrm{ppm}$ can be assigned to the trans-CO ligand and that at $183.2 \mathrm{ppm}$ to the cis-CO ligand (relative to NHC). Thus, it is the cis-CO ligand that undergoes a fast $\mathrm{CO}$ exchange. The same dynamic behavior is observed for complex ${ }^{13} \mathrm{C}_{\mathbf{2}} \mathbf{b}$ containing the tert-butyl substituted dipyridocarbene ligand dipiy ${ }^{\mathrm{tBu}}$. For iridium complexes $\left[\mathrm{Ir}(\mathrm{CO})_{2} \mathrm{Cl}(\mathrm{NHC})\right](\mathrm{NHC}=$ imidazolidin-2ylidene) a preferred cis-CO exchange was reported and an activation energy of $12.7-12.9 \mathrm{kcal} / \mathrm{mol}$ was determined by NMR

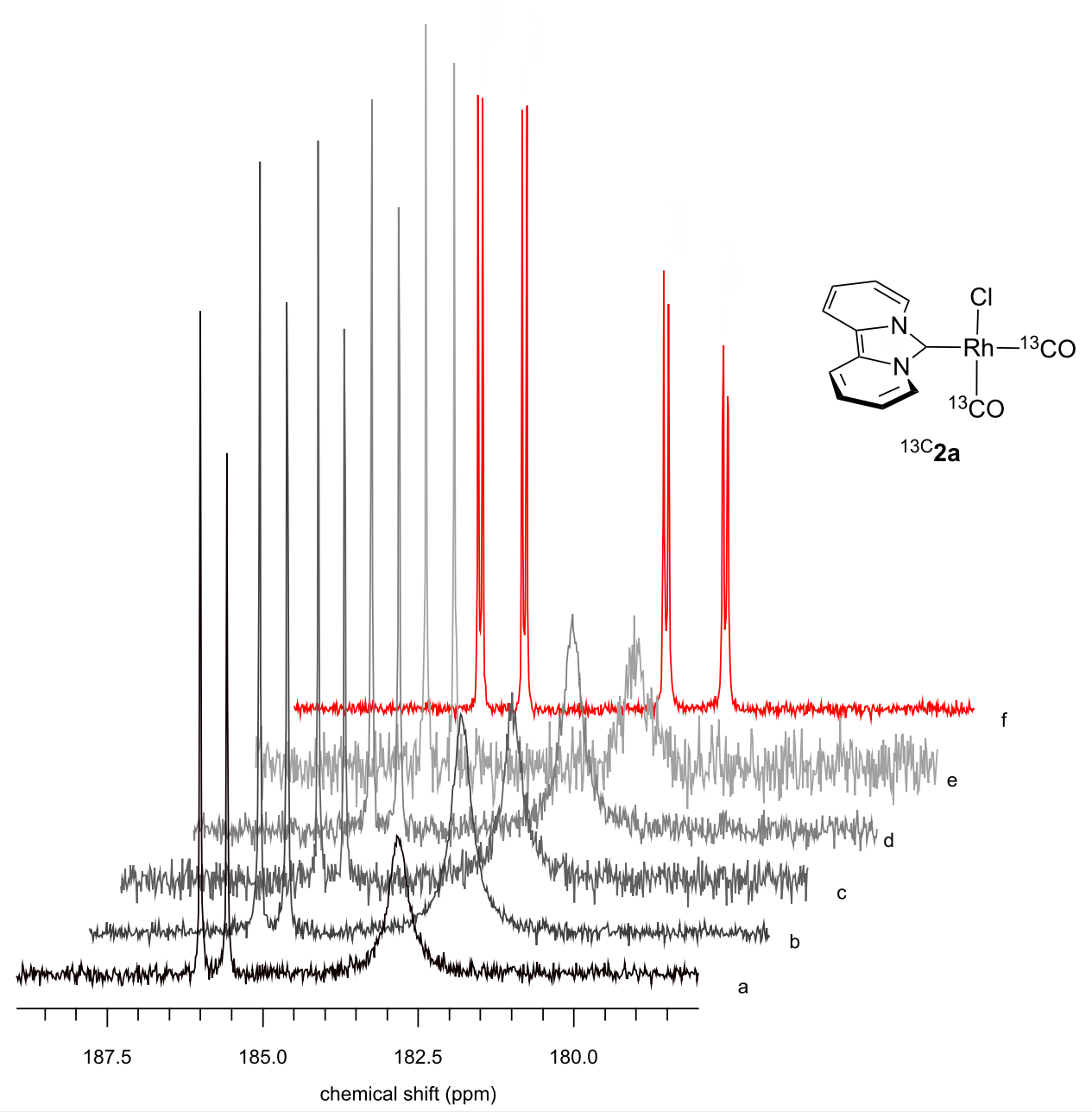

Figure 2: ${ }^{13} \mathrm{C}$ NMR spectra (carbonyl region, $125 \mathrm{MHz}$ ) of the reaction of $1 \mathrm{a}$ with ${ }^{13} \mathrm{CO}$ under variable pressure and temperature: left: a) 6 bar ${ }^{13} \mathrm{CO}$, $-30{ }^{\circ} \mathrm{C}$; b) 6 bar ${ }^{13} \mathrm{CO},-50{ }^{\circ} \mathrm{C}$; c) 1 bar ${ }^{13} \mathrm{CO},-30{ }^{\circ} \mathrm{C}$; d) 1 bar ${ }^{13} \mathrm{CO},-50{ }^{\circ} \mathrm{C}$; e) grey: 1 bar $\mathrm{N}_{2}$ and residual ${ }^{13} \mathrm{CO}$, rt; f) red: ${ }^{13} \mathrm{CO}-$ free solution, rt, 75 $\mathrm{MHz}$. 
spectroscopy for this process [60]. However, an exchange of the $\mathrm{CO}$ ligand by phosphines in $\left[\mathrm{M}(\mathrm{CO})_{2} \mathrm{Cl}(\mathrm{NHC})\right]$ complexes ( $\mathrm{M}=\mathrm{Rh}, \mathrm{Ir})$ or even by DMSO [60-62] occurs at the trans-CO ligand. In some cases, loss of CO upon formation of dimers can be observed for rhodium NHC complexes [63-65].

Ligand exchange in square planar Rh(I) carbonyl complexes was shown to occur by an associative mechanism via a trigonal bipyramidal intermediate $[66,67]$, which was also crystallographically characterized in the case of a cationic $\mathrm{Rh}$ complex bearing a bidentate phosphine ligand [68]. Our DFT-calculations for the tricarbonyl complex 3a bearing the dipiy ligand show that the pentacoordinated intermediate 3a NHC/COapic, in which the $\mathrm{NHC}$ and the former trans-CO ligand take in the apical positions, is energetically favored over that with $\mathrm{Cl}^{-}$and the former cis-CO ligand in the apical positions (3a Cl/COapic) by $16.9 \mathrm{~kJ} / \mathrm{mol}$ (Scheme 2). The calculated data is similar for complexes with the unsaturated NHC ligand III, which favors the respective NHC/COapic intermediate by $14.9 \mathrm{~kJ} / \mathrm{mol}$. Assuming similar low activation barriers for the $\mathrm{CO}$ association and the dissociation, release of the $\mathrm{CO}$ ligand from the trigonal plane in the intermediate 3a NHC/COapic leads to the preferred exchange of the cis-CO ligand (Scheme 2). This is in accordance with the experimental observation of the ${ }^{13} \mathrm{CO}$ exchange. Although the formation of 3a NHC/COapic from $2 \mathbf{a}$ and $\mathrm{CO}$ is exothermic $\left(\Delta H_{298 \mathrm{~K}, 1 \mathrm{bar}}=-11.4 \mathrm{~kJ} / \mathrm{mol}\right)$, considering the entropy leads to an endergonic reaction $\left(\Delta G_{298 \mathrm{~K}, 1 \mathrm{bar}}=29.4 \mathrm{~kJ} / \mathrm{mol}\right)$, even at $-50{ }^{\circ} \mathrm{C}$ and $6 \mathrm{bar}$ $\left(\Delta G_{223 \mathrm{~K}, 6 \mathrm{bar}}=15.7 \mathrm{~kJ} / \mathrm{mol}\right)$.

On a preparative scale, complexes $\mathbf{2 a}$ and $\mathbf{2 b}$ were synthesized in a glass autoclave with a $\mathrm{CO}$ pressure of 8 bar. In both cases the carbene ${ }^{13} \mathrm{C}$ NMR signals $\left(-30{ }^{\circ} \mathrm{C}, \mathrm{CD}_{2} \mathrm{Cl}_{2}\right)$ could be detected at $152.2 \mathrm{ppm}\left({ }^{1} J_{\mathrm{RhC}}=43.6 \mathrm{~Hz}\right)(\mathbf{2 a})$ and at $150.3 \mathrm{ppm}$ $\left({ }^{1} J_{\mathrm{RhC}}=44.4 \mathrm{~Hz}\right)(\mathbf{2 b})$. The carbonyl signals are detected at $182.5\left({ }^{1} J_{\mathrm{RhC}}=72.7 \mathrm{~Hz} ;\right.$ cis-CO $)$ and $185.9 \mathrm{ppm}$ $\left({ }^{1} J_{\mathrm{RhC}}=54.0 \mathrm{~Hz}\right.$; trans-CO) for complex $2 \mathrm{a}$ and at 182.8 $\left({ }^{1} J_{\mathrm{RhC}}=75.8 \mathrm{~Hz}\right.$; cis-CO $)$ and $186.1 \mathrm{ppm}\left({ }^{1} J_{\mathrm{RhC}}=53.6 \mathrm{~Hz}\right.$; trans-CO) for complex $\mathbf{2 b}$.

To compare the IR stretching frequencies with other Rh-complexes in literature, we determined the symmetric and asymmetric CO stretching modes of complex 2a in dichloromethane $\left(\tilde{v}=2082\right.$ and $\left.2003 \mathrm{~cm}^{-1}\right)$, dimethyl sulfoxide $(\tilde{v}=2064$ and $\left.1984 \mathrm{~cm}^{-1}\right)$ and as a KBr pellet $\left(\tilde{v}=2073\right.$ and $\left.1993 \mathrm{~cm}^{-1}\right)$. This large medium dependence shows that it is mandatory to compare the stretching frequencies analyzed in the same medium. As the difference of the symmetric and the asymmetric $\mathrm{CO}$ stretching frequencies is not constant, it is common to compare the average value of these two bands. Table 1 gives an overview of the $\mathrm{CO}$ stretching frequencies of $\left[\mathrm{Rh}(\mathrm{CO})_{2} \mathrm{Cl}(\mathrm{L})\right]$ complexes with the most common types of NHC ligands L.

A graphical illustration of these values is depicted in Figure 3. It shows that the dipyrido-annelated carbenes have an overall donor capacity that lies in between that of acyclic (Ia) or ferrocene bridged (Ib) diaminocarbenes and saturated imidazolidin2-ylidenes (II). This is surprising, as the $\sigma$-donor character of dipyridocarbenes is lower than that of the unsaturated imidazolin-2-ylidenes (III) and triazolinylidenes (IV), as it can be derived from the low $\mathrm{N}-\mathrm{C}-\mathrm{N}$ angle $\left(99.6^{\circ}\right)$ which enhances the $\mathrm{s}$-character of the carbene $\sigma$-orbital and thus reduces the $\sigma$-donor character (deduced directly from the larger ${ }^{1} J_{\mathrm{CH}}$ coupling constant of the respective imidazolium salts that correlates with the higher s-character in the $\mathrm{C}-\mathrm{H}$ bond). Therefore, we expected the average $\mathrm{CO}$ stretching frequencies to lie about $15 \mathrm{~cm}^{-1}$ higher at around $2050 \mathrm{~cm}^{-1}$ for complexes $\mathbf{2 a}$ and $\mathbf{2 b}$.

This discrepancy can be explained by a substantial lower $\pi$-acceptor character than the generally low $\pi$-acceptor char-

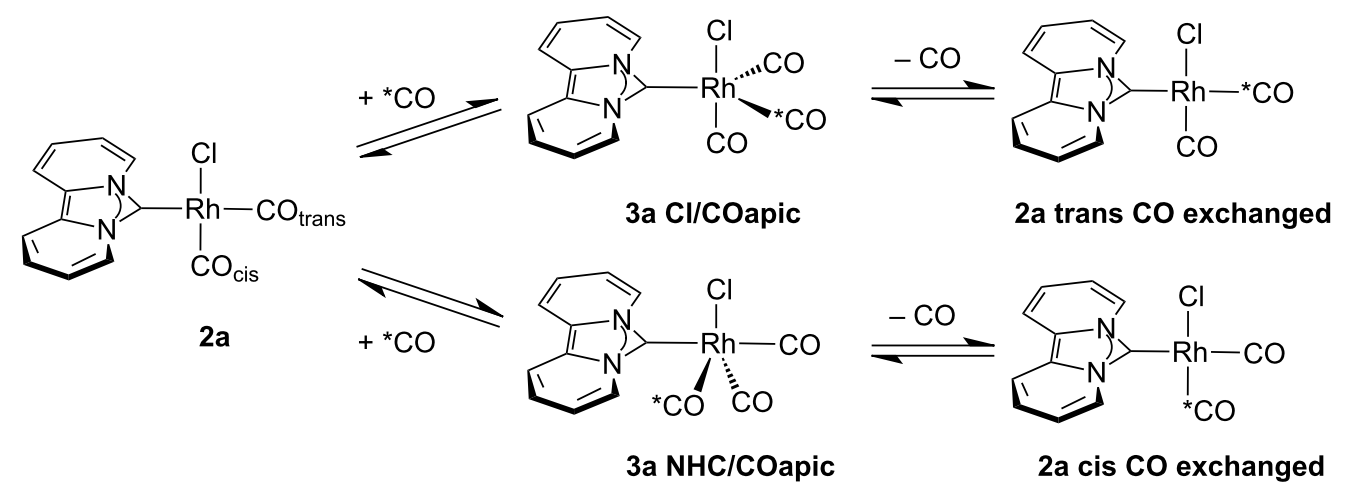

Scheme 2: Proposed mechanism for the preferred exchange of the cis-CO ligand based on DFT-calculations (BP86 / def2-TZVP) with the dipiy ligand. Intermediate 3a NHC/COapic is lower in energy by $16.9 \mathrm{~kJ} / \mathrm{mol}$ compared to intermediate $\mathbf{3 a} \mathbf{C l} / \mathbf{C O}$ apic. 


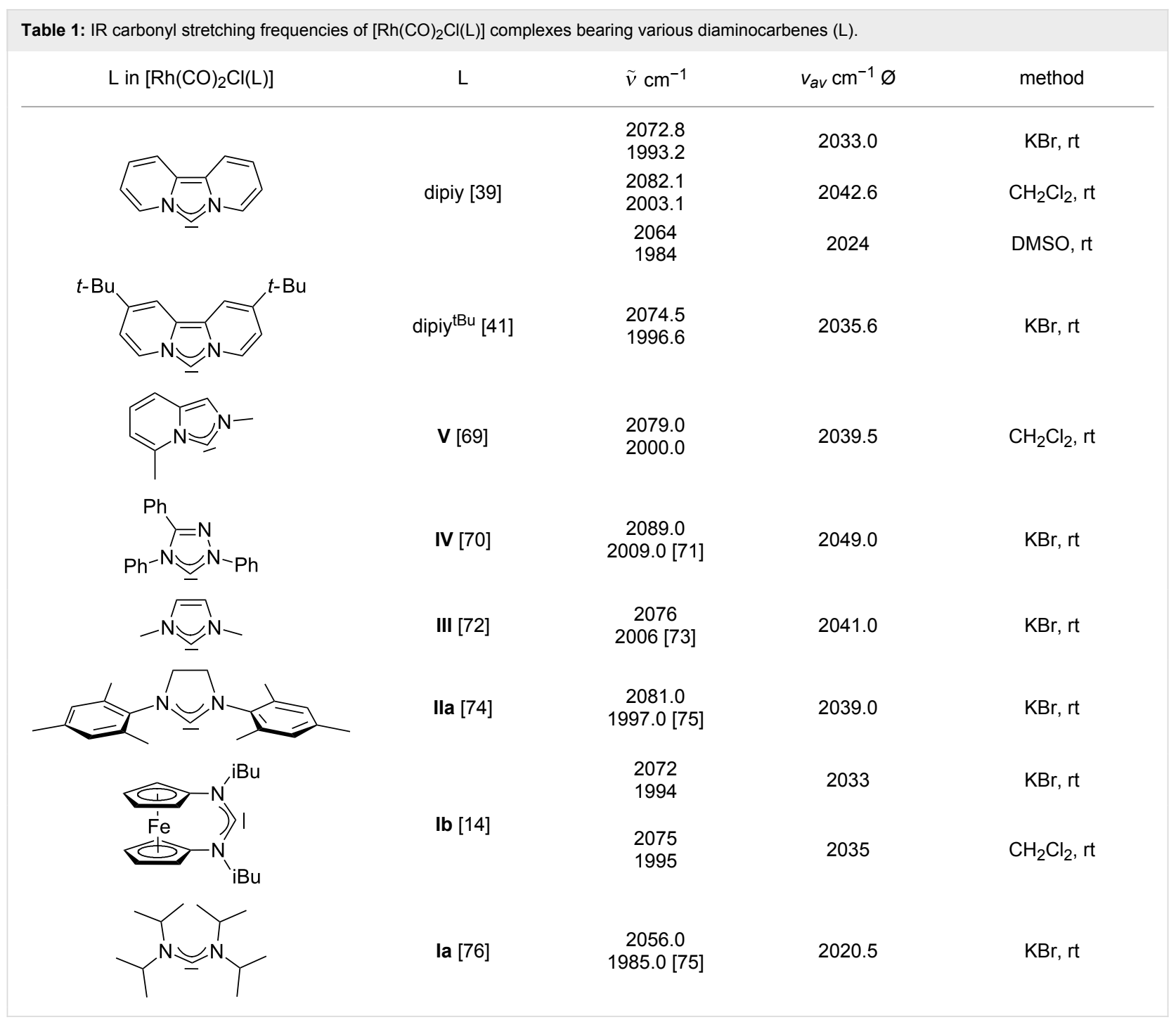

acter of carbenes. This may even be considered as a $\pi$-donor character - as proposed by Weiss and co-workers - to overcompensate the reduced $\sigma$-donor property. The description of Weiss and co-workers that dipyridocarbenes had a structural relationship "with "true" bis(ylides) such as carbodiphosphoranes" [39] illustrates very nicely the experimentally determined high overall donor effect of the dipyridocarbene reported herein.

The reason for this behavior seems to be the cross-conjugated $14 \pi \mathrm{e}^{-}$system into which the "empty" $\mathrm{p}_{\pi^{-}}$orbital of the carbene is embedded and therefore, could also act as a $\pi$-electron donor. To obtain further experimental evidence for this unusually weak $\pi$-acceptor (or already weak $\pi$-donor character), we determined the ${ }^{77} \mathrm{Se}$ NMR chemical shift of the respective selenourea $4 \mathbf{b}$ to be $-55.8 \mathrm{ppm}$ [77]. This value is the most negative reported so far for imidazole derived selenoureas and therefore, is another hint for the unusually low $\pi$-accepting quality of the dipyridocarbene family dipiy.

To rationalize these strong overall donating properties we performed DFT calculations of the free dipyridocarbene dipiy and its $\mathrm{Rh}(\mathrm{CO})_{2} \mathrm{Cl}$ complex $\mathbf{2 a}$, as well as the acyclic (I, I-Rh, Ia, Ia-Rh), saturated (II, II-Rh) and unsaturated (III, III-Rh) diaminocarbenes and their rhodium complexes.

Firstly, we could confirm the trend of the IR stretching frequencies for the calculated complexes although the differences are smaller between Ia-Rh, 2a, II-Rh and III-Rh (Table 2) than observed experimentally. The complex with the isopropyl acyclic carbene Ia-Rh shows its unique electron donating effect also in the calculations. The smaller differences found for the calculated $\mathrm{CO}$ stretching frequencies are independent of the used functionals (BP86 and B3LYP). Both functionals lead to 


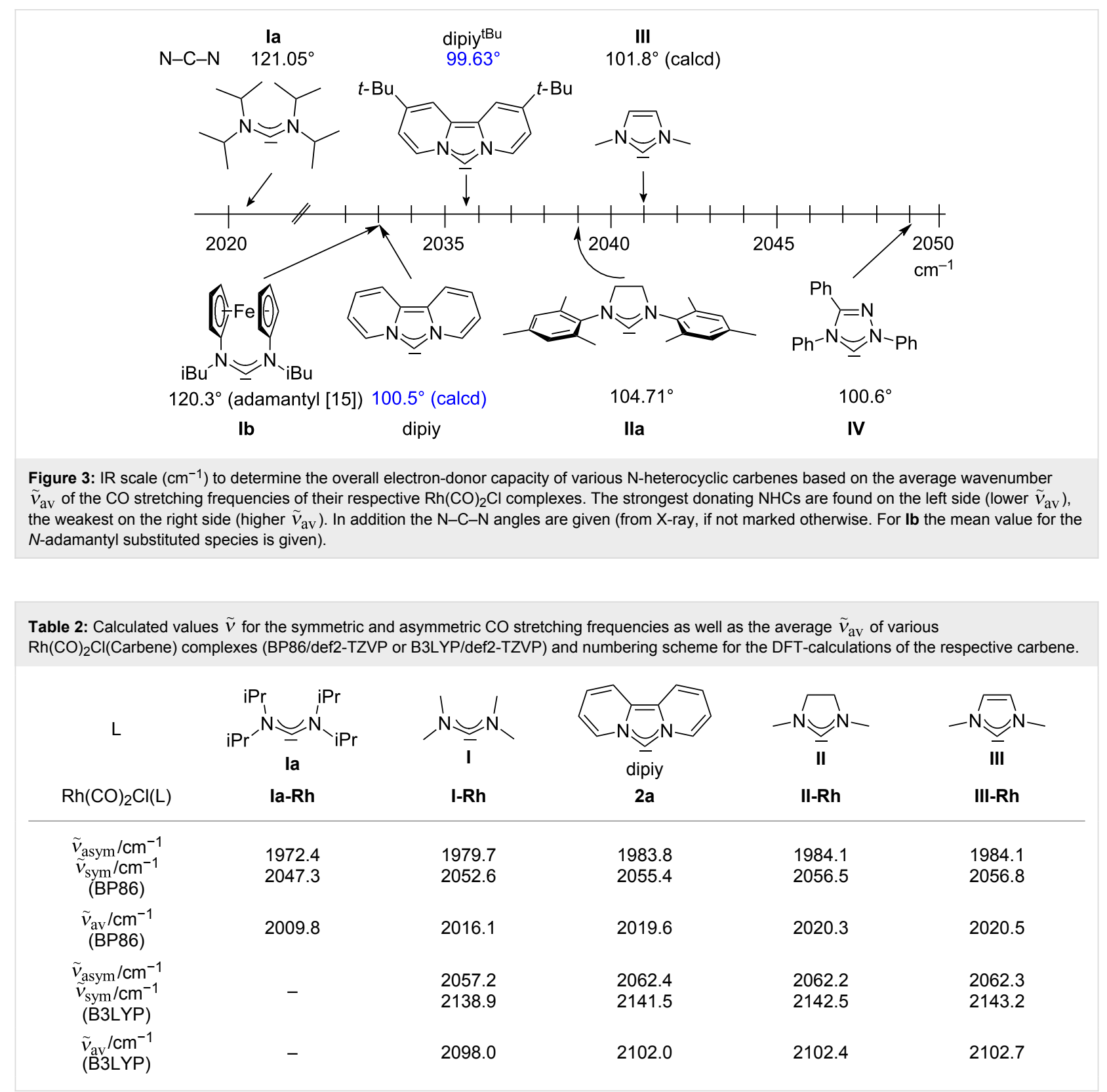

comparable results with respect to the experimental values when calibrated to free CO $\left(2125 \mathrm{~cm}^{-1}\right.$ (BP86), $2208 \mathrm{~cm}^{-1}$ (B3LYP), exp. $2143 \mathrm{~cm}^{-1}$ ).

To obtain information to which extent the carbene ligands act as an overall $\pi$-electron acceptor (or $\pi$-donor), we analyzed the electron occupation of the respective $\mathrm{p}_{\pi}$-orbital at the carbene performing a natural population analysis [78] (Table 3). As expected the stronger stabilization of the $\mathrm{p}_{\pi}$ orbital within the conjugated $14 \pi \mathrm{e}^{-}$system results in a higher occupation for the carbene dipiy (0.738) at $\mathrm{C} 3$, which decreases in the order $6 \pi \mathrm{e}^{-}$ carbene III (0.687), $4 \pi \mathrm{e}^{-}$carbene II $(0.592)$ and the acyclic $4 \pi \mathrm{e}^{-}$carbene I (0.618) (Table 3$)$. For the rhodium complexes these values are higher, so that an overall $\pi$-electron-withdrawing character of the carbene ligand can be concluded. It is surprising that the largest increase in electron occupancy $\left(\triangle \mathrm{Rh}-\mathrm{NHC}^{-}(\mathrm{C} 3)\right)$ is found for the dipyridocarbene dipiy (0.16) and the weakest for the acyclic carbene (I) (0.12). However, the increase must not necessarily stem from electron density of the metal center. It could also originate from the $\pi$-system of the respective carbene. Therefore, we also calculated the sum of the $\mathrm{p}_{\pi}$-electron occupancy for the free carbene as well as for the complex (which should sum up to $4 \mathrm{e}^{-}$(I and II), $6 \mathrm{e}^{-}$(III) or $14 \mathrm{e}^{-}$(dipiy), respectively). It now becomes clear that the overall gain in $\pi$-electron occupancy $\Delta_{\mathrm{Rh}-\mathrm{NHC}} \mathrm{e}^{-}$ is highest in the case of the saturated carbene II $(0.08)$ and 
Table 3: Electron occupation $\left(\mathrm{e}^{-}\right)$of the $\mathrm{p}_{\pi}$ orbital at the carbene atom C3 and at the other atoms of the $\pi$-system in the free carbenes I-III and dipiy and in their Rh carbonyl complexes.

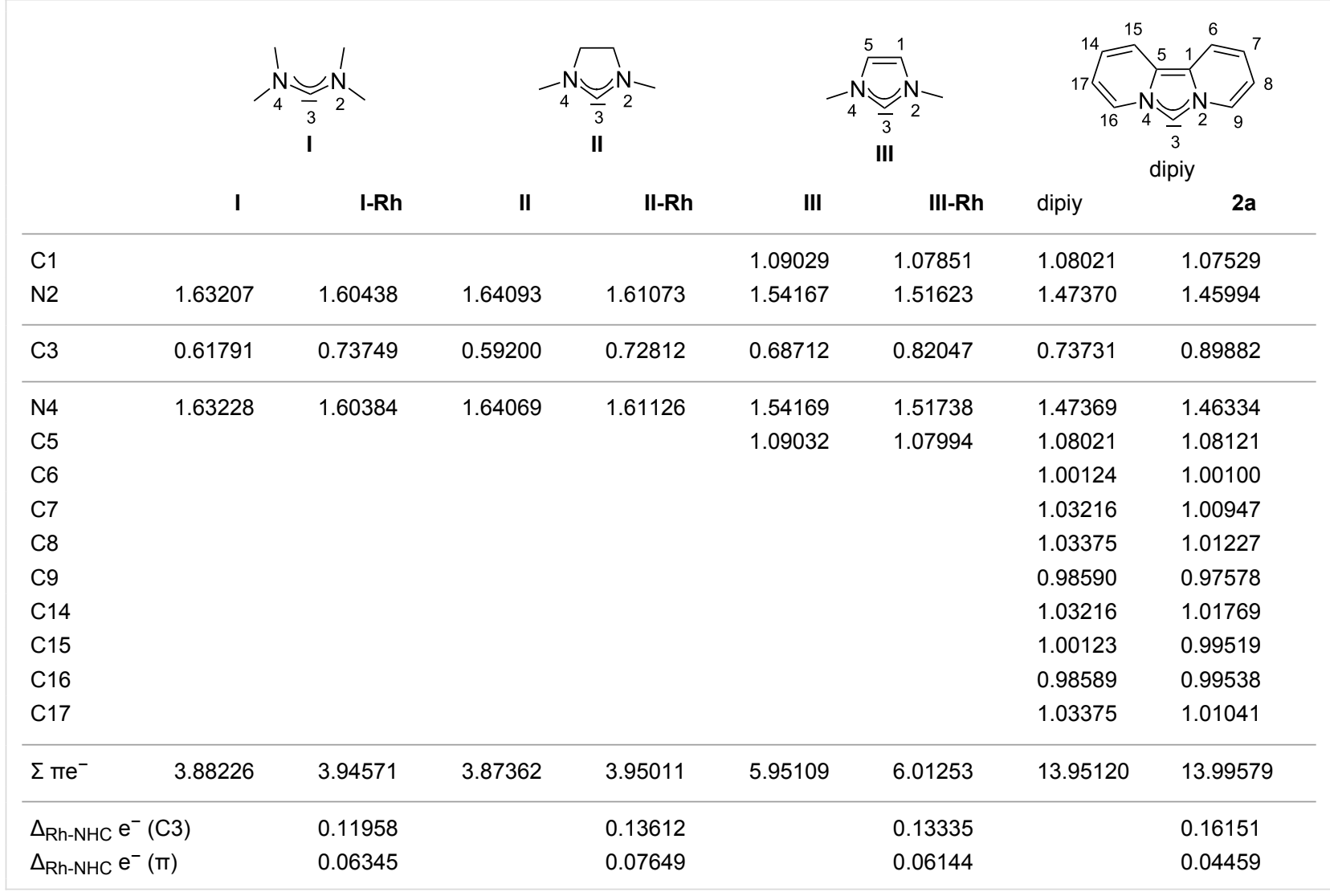

smallest for the dipyridocarbene dipiy (0.04). It may therefore be concluded that dipiy is the carbene with the weakest $\pi$-acceptor character. In addition, the role of a potential net $\pi$-donor character of the dipyridocarbene dipiy can be ruled out in the Rh complex 2a. A less electron-rich metal center might induce a net $\pi$-donor property in this carbene.

It is known from theoretical studies that a reduction of the $\mathrm{N}-\mathrm{C}-\mathrm{N}$ angle leads to a stabilization of the carbene $\sigma$-orbital [40]. At the same time the extended conjugated $\pi$-system leads to an energy increase of the highest occupied $\pi$-orbital and a smaller HOMO-LUMO gap. Analyzing the molecular orbitals of the free carbenes I-III and dipiy reveals that in dipiy the carbene $\sigma$-orbital is no longer the highest occupied orbital, but it is found stabilized by $0.58 \mathrm{eV}$ as the HOMO- $1(-5.18 \mathrm{eV})$. The $\mathrm{HOMO}$ at $-4.60 \mathrm{eV}$ is located at the $\pi$-system (see Figure 4). This has only been observed for the bisoxazoline-derived IBioxMe 4 carbene before, whose calculated $\mathrm{N}-\mathrm{C}-\mathrm{N}$ angle of $98.6^{\circ}$ is even more acute than that of dipiy [79]. For dipiy the other 6 occupied MOs of the $14 \pi \mathrm{e}^{-}$system are found between $-6.28 \mathrm{eV}$ and $-11.7 \mathrm{eV}$ (HOMO-2 to HOMO-5, HOMO-10 and HOMO-14, see Supporting Information File 1 for a graphi-

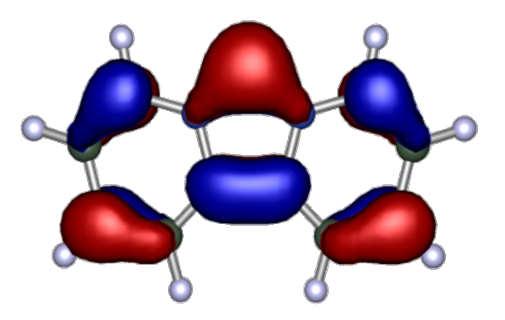

HOMO $-4.60 \mathrm{eV}$

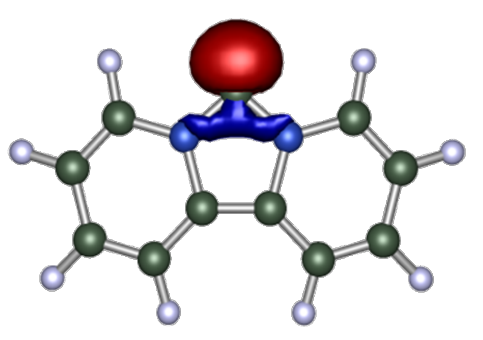

$\mathrm{HOMO}-1$ $-5.18 \mathrm{eV}$

Figure 4: Highest occupied molecular orbitals for the dipyrido-annelated carbene dipiy. The $\sigma$-type carbene lone pair is not the HOMO but the HOMO-1. 
cal comparison of the highest occupied MOs of I-III and dipiy).

The energy gain $\left(\Delta E_{\sigma}\right)$ of the $\sigma$-orbitals upon coordination to the rhodium fragment is by far highest for the acyclic carbene $\mathbf{I}$ $(4.14 \mathrm{eV})$ and lowest for the dipyridocarbene carbene dipiy $(3.30 \mathrm{eV})$ (II: $3.57 \mathrm{eV}$; III: $3.66 \mathrm{eV})$ which displays the order of decreasing $\sigma$-donor character (and the decreasing $\mathrm{N}-\mathrm{C}-\mathrm{N}$ angle) of these carbenes.

For the Rh-complexes I-Rh-III-Rh two type of orbitals that indicate a ligand to metal $\pi$-donor bond are revealed. One is found for the II-Rh complex between the HOMO-2 of the ligand and the $d_{x y}$ orbital of $R h$ (plus contributions of the chlorido and the antibonding $\pi$-orbital of the cis-CO ligand) at $-9.07 \mathrm{eV}$ (HOMO-9) (Figure 5). The other is found between the HOMO -1 of the carbene ligand and the $\mathrm{d}_{\mathrm{xy}}$ orbital of $\mathrm{Rh}$ in complex III-Rh (plus contributions of the chlorido and the antibonding $\pi$-orbital of the cis- and trans-CO ligands) at $-7.85 \mathrm{eV}$. In the case of the dipiy ligand both of these orbital types are recognized at $-7.61 \mathrm{eV}(\mathrm{HOMO}-8)$ and $-9.13 \mathrm{eV}$ (HOMO-12). Tentatively, this could indicate an overall stronger $\pi$-donor contribution of this ligand. A molecular orbital that shows an in plane metal-to-ligand $\pi$-interaction with the carbene $\sigma^{*}(\mathrm{C}-\mathrm{N})$ orbitals [79] was not observed.

\section{Explaining the observed $\mathrm{CO}$ stretching frequencies}

The CO stretching frequencies of imidazolium-derived carbene complexes of Rh are influenced by the sum of $\sigma$ and $\pi$-donor as well as the $\pi$-acceptor character of the carbenes. In acyclic diaminocarbene complexes of type $\mathbf{I}$ the strong $\sigma$-donor character dominates as evidenced by the large $\mathrm{N}-\mathrm{C}-\mathrm{N}$ angles and the high lying $\sigma$-orbital (HOMO). In the case of complex Ia-Rh bearing the isopropyl substituted carbene Ia, the steric hindrance of the $N$-isopropyl substituents causes an even larger $\mathrm{N}-\mathrm{C}-\mathrm{N}$ angle. This leads to a further reduction of the s-character and thus an increased $\sigma$-donor character that explains the pronounced shift to smaller wavenumbers. According to our DFT calculations, the saturated and unsaturated carbenes have an almost similar donor character so that the weaker $\sigma$-donor character is almost compensated by a reduced $\pi$-acceptor character. In complexes $\mathbf{2} \mathbf{a}$ and $\mathbf{2} \mathbf{b}$ bearing the pyridoannelated carbenes dipiy and dipiy ${ }^{\mathrm{tBu}}$, the extremely weak $\pi$-acceptor character overcompensates the weaker $\sigma$-donor effect, so that the overall donor property of the carbene increases and results in $\mathrm{CO}$ stretching frequencies that lie in between those of the acyclic (I-Rh) and the saturated carbene complex (II-Rh).

\section{Conclusion}

We prepared and analyzed both experimentally and theoretically the dipyridocarbene rhodium carbonyl complexes $\mathbf{2 a}$ and $\mathbf{2 b}$. We showed that the $\mathrm{CO}$ exchange of the cis-CO ligand is enhanced over that of the trans-CO ligand. The unusually high overall donating property of the dipyridocarbenes dipiy exceeds that of imidazolidinylidenes (II) and was revealed by IR spectroscopy. The unusually weak $\pi$-acceptor character of the dipyridocarbenes was evidenced by the so far lowest ${ }^{77}$ Se NMR chemical shift for imidazole-derived carbenes. Comparing the
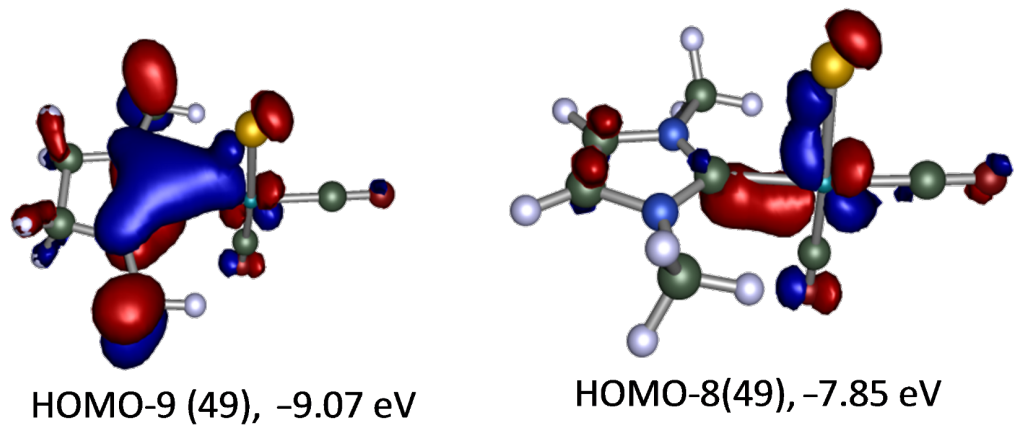

II-Rh

III-Rh

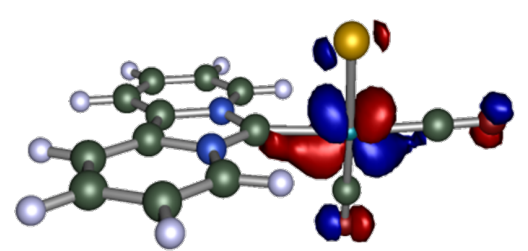

HOMO-8 (67), $-7.61 \mathrm{eV}$

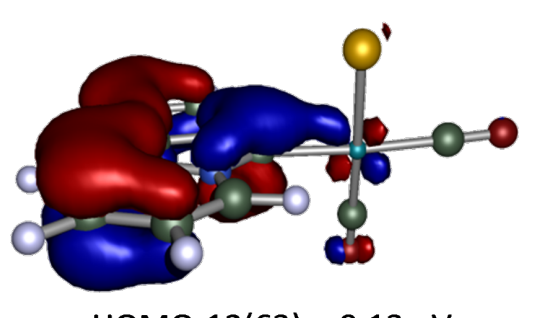

HOMO-12(63), $-9.13 \mathrm{eV}$

2a 
electron occupancy in the $\pi$-system of the free and the coordinated carbene revealed still a, although very low, net $\pi$-acceptor character of the dipyridocarbene. We are convinced that less electron-rich metal fragments could induce an overall $\pi$-donor character in dipyridocarbenes and could thus proof the "built-in umpolung" [39] ability proposed by Weiss and co-workers This property might be advantageous to stabilize low coordinated metal fragments in higher oxidation states, for example intermediates of catalytic reactions.

\section{Experimental}

General information. All reactions were carried out under an inert argon atmosphere in dried and degassed solvents using standard Schlenk techniques. All metal complexes were handled in an MBraun glovebox with a nitrogen atmosphere. Solvents were dried according to standard procedures. $\left[\mathrm{Rh}\right.$ (dipiy)Cl(cod)] (1a), [Rh(dipiy $\left.\left.{ }^{\mathrm{tBu}}\right) \mathrm{Cl}(\operatorname{cod})\right]$ (1b) [56] and the dipyridoimidazolium salt dipiy ${ }^{\mathrm{tBu} *} \mathrm{HBF}_{4}$ [41] were prepared according to literature procedures. NMR spectra were recorded using Bruker instruments (DRX-250, 300 or 500 ). ${ }^{1} \mathrm{H}$ and ${ }^{13} \mathrm{C}$ NMR spectra were referenced to TMS on the basis of the (residual) signal of the deuterated solvent. ${ }^{77} \mathrm{Se}$ NMR shifts were calibrated towards $\mathrm{Ph}_{2} \mathrm{Se}_{2}(463 \mathrm{ppm})$ in $\mathrm{CDCl}_{3}$ as an external standard [80]. Medium-wall NMR tubes with a PTFE valve from Wilmad were used for the NMR experiments under $\mathrm{CO}$ pressure. IR spectra were recorded on a Bruker Equinox 55 FTIR spectrometer as a $\mathrm{KBr}$ pellet or in solution. Mass spectra were recorded on a Jeol JMS-700 and the melting point was determined with a Büchi Melting Point B 540 apparatus. The elemental analysis was carried out at Mikroanalytisches Laboratorium der Chemischen Institute of Heidelberg University. All experiments except for the synthesis and the analysis of the selenourea 4 (Institut für Anorganische Chemie of the University of Tübingen) were carried out at the Organisch-Chemisches Institut of Heidelberg University.

Calculations. All calculations were performed based on density functional theory at the BP86/def2-TZVP [81-85] or B3LYP/ def2-TZVP [86-88] level implemented in Turbomole [89-97]. The RI-approximation [98-103] and def2-ecp [104] for Rh were used all over (in case of compounds $\mathbf{3 a}$ also the D3-correction [105]). All structures were verified to be minimum structures by calculating Hessian matrices and ensuring that they have no imaginary frequency. Graphics of the MOs were prepared using POV-Ray $^{\text {TM }}[106]$.

NMR experiment for the in situ generation of [Rh $\left({ }^{13} \mathrm{CO}\right)_{2} \mathrm{Cl}($ dipyrido[1,2-c;2',1'-e]imidazolin-6-ylidene)] $\left({ }^{13 C} \mathbf{2 a}\right)$. A medium wall NMR tube was charged with a yellow solution of $6.0 \mathrm{mg}(15 \mu \mathrm{mol})$ [ $\mathrm{RhCl}(\mathrm{COD})($ dipiy)] (1a) in $0.4 \mathrm{~mL} \mathrm{CD}_{2} \mathrm{Cl}_{2}$ and pressurized with 6 bar of ${ }^{13} \mathrm{CO}$ upon which a yellow precipitate formed that dissolved immediately and the solution turned greenish yellow. The signals of non-coordinated COD were observed as the only side product. ${ }^{1} \mathrm{H}$ NMR (300.13 MHz, $\mathrm{CD}_{2} \mathrm{Cl}_{2}$ ) $\delta$ 7.07-7.13 (m, 4H, 2-H, 3-H, 9-H, 10-H), 7.92-7.97 (m, 2H, 1-H, 11-H), 8.92-8.97 (m, 2H, 4-H, $8-\mathrm{H})$; Contains free COD: $\delta=2.31-2.36\left(\mathrm{~m}, 8 \mathrm{H}, \mathrm{CH}_{2}\right)$, 5.54-5.57 (m, 4H, CH); ${ }^{13} \mathrm{C}\left\{{ }^{1} \mathrm{H}\right\}$ NMR $\left(75.5 \mathrm{MHz}, \mathrm{CD}_{2} \mathrm{Cl}_{2}\right) \delta$ 117.6 (C3, C9), 118.2 (C1, C11), 120.7 (C2, C10), 127.3 (C4, C8), 184.3 (free CO), $186.3\left(\mathrm{~d},{ }^{1} J_{\mathrm{RhC}}=54.6 \mathrm{~Hz}\right.$, trans $\left.{ }^{13} \mathrm{CO}\right)$. The signals of $\mathrm{C} 6$ and $\mathrm{C} 11 \mathrm{a} / 11 \mathrm{~b}$ were not detected; contains free COD $\left(\delta 28.6\left(\mathrm{CH}_{2}\right), 184.3(\mathrm{CH})\right)$.

NMR experiment of in situ generated $\left({ }^{\left.13 C_{2} a\right)}\right.$ at variable temperature. The experiment was repeated with a sample containing $7.0 \mathrm{mg}(17 \mu \mathrm{mol})[\mathrm{RhCl}(\mathrm{COD})($ dipiy)] (1a) in $0.4 \mathrm{~mL} \mathrm{CD} \mathrm{Cl}_{2}$ at 6 bar ${ }^{13} \mathrm{CO}$. NMR spectra were recorded at $-30{ }^{\circ} \mathrm{C}$ and $-50{ }^{\circ} \mathrm{C}$. Then the pressure was released and NMR spectra were recorded at $-50{ }^{\circ} \mathrm{C}$ and $-30{ }^{\circ} \mathrm{C}$. Afterward the sample was opened under nitrogen atmosphere and shaken to release free ${ }^{13} \mathrm{CO}$. NMR spectra were recorded at room temperature. Finally the solution was transferred to a regular J. Young ${ }^{\circledR}$ NMR tube and any residual ${ }^{13} \mathrm{CO}$ removed by three freeze-thaw cycles using liquid nitrogen. The NMR spectra of the sample were then recorded at room temperature. All spectra ${ }^{13} \mathrm{C}\left\{{ }^{1} \mathrm{H}\right\}$ NMR (125.8 MHz, $\mathrm{CD}_{2} \mathrm{Cl}_{2}$, only carbonyl region) $243 \mathrm{~K}, 6$ bar ${ }^{13} \mathrm{CO}$ : $\delta 183.0$ (broad peak, free and $\mathrm{cis}^{-1}{ }^{13} \mathrm{CO}$ ), $185.9\left(\mathrm{~d},{ }^{1} J_{\mathrm{RhC}}=53.6 \mathrm{~Hz}\right.$, trans $\left.{ }^{13} \mathrm{CO}\right) ; 223 \mathrm{~K}, 6$ bar ${ }^{13} \mathrm{CO}$ : $\delta 182.8$ (broad peak, free and $c i s{ }^{13} \mathrm{CO}$ ), 185.7 (d, ${ }^{1} J_{\mathrm{RhC}}=53.6 \mathrm{~Hz}$, trans ${ }^{13} \mathrm{CO}$ ); $223 \mathrm{~K}, 1$ bar ${ }^{13} \mathrm{CO}: \delta 182.8$ (free and cis $\left.{ }^{13} \mathrm{CO}\right), 185.7\left(\mathrm{~d},{ }^{1} J_{\mathrm{RhC}}=53.6 \mathrm{~Hz}\right.$, trans $\left.{ }^{13} \mathrm{CO}\right) ; 243 \mathrm{~K}$, 1 bar ${ }^{13} \mathrm{CO}: \delta 182.9$ (free and $c i s{ }^{13} \mathrm{CO}$ ), 185.9 (d, ${ }^{1} J_{\mathrm{RhC}}=53.6 \mathrm{~Hz}$, trans ${ }^{13} \mathrm{CO}$ ); $298 \mathrm{~K}, 1$ bar $\mathrm{N}_{2}: \delta 183.5$ (free and $\left.c i s-{ }^{13} \mathrm{CO}\right), 186.3\left(\mathrm{~d},{ }^{1} J_{\mathrm{RhC}}=55.5 \mathrm{~Hz}\right.$, trans $\left.{ }^{13} \mathrm{CO}\right) ; 298 \mathrm{~K}$, 1 bar $\mathrm{N}_{2}$, after freeze-thaw cycles: $\delta 183.2(\mathrm{dd}$, ${ }^{1} J_{\mathrm{RhC}}=72.8 \mathrm{~Hz},{ }^{2} J_{\mathrm{CC}}=6.1 \mathrm{~Hz}$, cis $\left.{ }^{13} \mathrm{CO}\right), 186.3(\mathrm{dd}$, ${ }^{1} J_{\mathrm{RhC}}=54.5 \mathrm{~Hz},{ }^{2} J_{\mathrm{CC}}=6.1 \mathrm{~Hz}$, trans $\left.{ }^{13} \mathrm{CO}\right)$.

NMR experiment for the in situ generation of $\left[\mathrm{Rh}\left({ }^{13} \mathrm{CO}\right)_{2} \mathrm{Cl}\left(2,10\right.\right.$-di-tert-butyldipyrido $\left[1,2-c ; 2^{\prime}, 1^{\prime}-e\right]$ imidazolin-6-ylidene)] $\left({ }^{13 C_{2}} \mathbf{b}\right)$. A medium-wall NMR tube was charged with a yellow solution of $10.0 \mathrm{mg}(20.0 \mu \mathrm{mol})$ [RhCl(COD)(dipiy $\left.\left.{ }^{\mathrm{tBu}}\right)\right](\mathbf{1 b})$ in $0.4 \mathrm{~mL} \mathrm{CD}_{2} \mathrm{Cl}_{2}$ and pressurized with 6 bar of ${ }^{13} \mathrm{CO}$. The signals of non-coordinated COD were observed as the only side product. ${ }^{1} \mathrm{H}$ NMR $(300.13 \mathrm{MHz}$, $\left.\mathrm{CD}_{2} \mathrm{Cl}_{2}\right) \delta 1.39\left(\mathrm{~s}, 18 \mathrm{H}, \mathrm{C}\left(\mathrm{CH}_{3}\right)_{3}\right), 7.13\left(\mathrm{dd},{ }^{3} J_{\mathrm{HH}}=7.5 \mathrm{~Hz}\right.$, $\left.{ }^{4} J_{\mathrm{HH}}=1.9 \mathrm{~Hz}, 2 \mathrm{H}, 3-\mathrm{H}, 9-\mathrm{H},\right), 7.76$ (bs, 2H, 1-H, 11-H), 8.82 $\left(\mathrm{d},{ }^{3} \mathrm{~J}_{\mathrm{HH}}=7.5 \mathrm{~Hz}, 2 \mathrm{H}, 4-\mathrm{H}, 8-\mathrm{H}\right)$. Contains free COD $(\delta 2.35$ (br m, 8H, $\mathrm{CH}_{2}$ ), 5.55 (br m, 4H, CH); ${ }^{13} \mathrm{C}\left\{{ }^{1} \mathrm{H}\right\} \mathrm{NMR}$

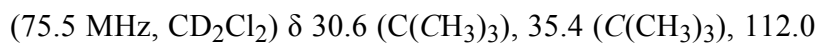
(C1, C11), 117.2 (C3, C9), 123.9 (C11a, C11b), 126.7 (C4, C8), 143.9 (C2, C10), 184.1 (broad peak, free and $\left.c i s-{ }^{13} \mathrm{CO}\right) 186.6$ 
$\left(\mathrm{d},{ }^{1} J_{\mathrm{RhC}}=55.4 \mathrm{~Hz}\right.$, trans $\left.{ }^{13} \mathrm{CO}\right)$. The carbene signal $\mathrm{C} 6$ was not detected; contains free COD $\left(\delta 28.6\left(\mathrm{CH}_{2}\right), 129.2(\mathrm{CH})\right)$.

Synthesis of $\left[\mathrm{Rh}(\mathrm{CO})_{2} \mathrm{Cl}\left(\right.\right.$ dipyrido $\left[1,2-c ; 2^{\prime}, 1^{\prime}-e\right]$ imidazolin6-ylidene)] (2a). In a $25 \mathrm{~mL}$-size glass autoclave was dissolved [RhCl(COD)(dipiy)] (1a) $(60.0 \mathrm{mg}, 150 \mu \mathrm{mol})$ in $5 \mathrm{~mL}$ dichloromethane and pressurized with $\mathrm{CO}(8$ bar) upon which an immediate color change to green was observed. Afterwards the pressure was released and all volatiles removed in vacuo. The light yellow residue was washed two times with pentane $(1 \mathrm{~mL}$ each) and dried in vacuo to obtain the carbonyl complex 2a in $93 \%$ yield $(47.0 \mathrm{mg}, 130 \mu \mathrm{mol}) . \mathrm{Mp} 259-262{ }^{\circ} \mathrm{C}(\mathrm{dec})$; ${ }^{1} \mathrm{H}$ NMR (300.13 MHz, $\left.\mathrm{CD}_{2} \mathrm{Cl}_{2}\right) \delta$ 7.07-7.14 (m, 4H, 2-H, 3-H, 9-H, 10-H), 7.93-7.96 (m, 2H, 1-H, 11-H), 8.93-8.96 (m, 2H, 4-H, 8-H); ${ }^{13} \mathrm{C}\left\{{ }^{1} \mathrm{H}\right\}$ NMR $\left(-30{ }^{\circ} \mathrm{C}, 75.5 \mathrm{MHz}, \mathrm{CD}_{2} \mathrm{Cl}_{2}\right) \delta 117.3$ (C3, C9), 117.8 (C1, C11), 120.2 (C2, C10), 123.4 (C11a, $\mathrm{C} 11 \mathrm{~b}), 126.4(\mathrm{C} 4, \mathrm{C} 8), 152.2\left(\mathrm{~d},{ }^{1} J_{\mathrm{RhC}}=43.6 \mathrm{~Hz}, \mathrm{C} 6\right), 182.5$ $\left(\mathrm{d}, \mathrm{C}_{\mathrm{CO}},{ }^{1} J_{\mathrm{RhC}}=72.7 \mathrm{~Hz}\right.$, cis-CO), $185.9\left(\mathrm{~d},{ }^{1} J_{\mathrm{RhC}}=54.0 \mathrm{~Hz}\right.$, trans-CO); IR (KBr, cm $\left.{ }^{-1}\right) \tilde{v}: 3105(\mathrm{w}), 3058(\mathrm{w}), 2963(\mathrm{w})$, 2073 (s, CO), 1993 (s, CO), 1622 (w), 1355 (w), 1331 (w), 739 (m), $704(\mathrm{w}) ;\left(\mathrm{CH}_{2} \mathrm{Cl}_{2}, \mathrm{~cm}^{-1}\right) \tilde{v}: 2082$ (m, CO), 2003 (m, CO); $\left(\mathrm{DMSO}, \mathrm{cm}^{-1}\right) \tilde{v}: 2064(\mathrm{~m}, \mathrm{CO}), 1984$ (m, CO); MS (FD ${ }^{+}$, $\mathrm{LIFDI}^{+}$in $\mathrm{CH}_{2} \mathrm{Cl}_{2}$ ) $\mathrm{m} / \mathrm{z}: 362.0\left[\mathrm{M}^{+}\right]$; anal. calcd for $\mathrm{C}_{13} \mathrm{H}_{8} \mathrm{ClN}_{2} \mathrm{O}_{2} \mathrm{Rh}: \mathrm{C}, 43.06$; $\mathrm{H}, 2.39$; N, 7.73; found: C, 42.88; $\mathrm{H}, 2.22 ; \mathrm{N}, 7.65$.

Synthesis of $\left[\mathrm{Rh}(\mathrm{CO})_{2} \mathrm{Cl}(2,10\right.$-di-tert-butyldipyrido[1,2c;2',1'-e]imidazolin-6-ylidene)] (2b). [ $\mathrm{RhCl}(\mathrm{COD})\left(\right.$ dipiy $\left.\left.^{\mathrm{tBu}}\right)\right]$ (1b) $(15.0 \mathrm{mg}, 30.0 \mu \mathrm{mol})$ was dissolved in $2.5 \mathrm{~mL}$ dichloromethane and pressurized with $\mathrm{CO}(8 \mathrm{bar})$ in a $10 \mathrm{~mL}$-size glass autoclave. After $10 \mathrm{~min}$ the pressure was released and all volatiles were removed in vacuo. The residue was washed with pentane $(1 \mathrm{~mL})$ and dried in vacuo to obtain about 50\% (7.0 mg, $15 \mu \mathrm{mol})$ of the carbonyl complex $\mathbf{2 b}$ as a yellow solid. ${ }^{13} \mathrm{C}\left\{{ }^{1} \mathrm{H}\right\}$ NMR $\left(243 \mathrm{~K}, 125.8 \mathrm{MHz}, \mathrm{CD}_{2} \mathrm{Cl}_{2}\right) \delta 30.0\left(\mathrm{C}\left(\mathrm{CH}_{3}\right)_{3}\right)$,

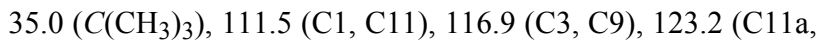
$\mathrm{C} 11 \mathrm{~b}), 126.1$ (C4, C8), 143.2 (C2, C10), 150.3 (d, $\left.{ }^{1} J_{\mathrm{RhC}}=44.4 \mathrm{~Hz}, \mathrm{C} 6\right), 182.8\left(\mathrm{~d},{ }^{1} J_{\mathrm{RhC}}=75.8 \mathrm{~Hz}\right.$, cis-CO $)$, $186.1\left(\mathrm{~d},{ }^{1} J_{\mathrm{RhC}}=53.6 \mathrm{~Hz}\right.$, trans-CO); IR $\left(\mathrm{KBr}, \mathrm{cm}^{-1}\right) \tilde{v}: 2962$ (s), 2868 (m), 2075 (s, CO), 1997 (s, CO), 1659 (w), 1533 (w), 1475 (w), 1366 (w), 1335 (w), 1300 (w), 1267 (m), 964 (m), $873(\mathrm{w}), 789(\mathrm{~m}), 638(\mathrm{~m}), 590(\mathrm{~m})$; HRMS $\left(\mathrm{FAB}^{+}\right.$in NBA) $m / z: 446.0612\left[\mathrm{M}\left({ }^{35} \mathrm{Cl}\right)-\mathrm{CO}^{+}\right]($calcd 446.0632$), 448.0596$ $\left[\mathrm{M}\left({ }^{37} \mathrm{Cl}\right)-\mathrm{CO}^{+}\right]($calcd 448.0603$), 474.0584\left[\mathrm{M}\left({ }^{35} \mathrm{Cl}\right)^{+}\right]($calcd 474.0581), 476.0581 [M( $\left.\left.{ }^{37} \mathrm{Cl}\right)^{+}\right]$(calcd 476.0552).

Synthesis of 2,10-di-tert-butyldipyrido[1,2-c:2',1'-e]imidazolin-6-selenone (4b). A suspension of 2,10-di-tertbutyldipyrido[1,2-c:2',1'-e]imidazolium tetrafluoroborate [41] $(40.5 \mathrm{mg}, 110 \mu \mathrm{mol})$ and selenium $(32.1 \mathrm{mg}, 407 \mu \mathrm{mol})$ in $3 \mathrm{~mL}$ of tetrahydrofuran was cooled to $-35^{\circ} \mathrm{C}$ and a solution of potassium tert-butoxide $(14.9 \mathrm{mg}, 133 \mu \mathrm{mol})$ in $1 \mathrm{~mL}$ tetraydrofuran was added. After $30 \mathrm{~min}$ the deep red suspension was warmed up to room temperature and stirred overnight. The solvent was removed in vacuo and the residue suspended in $7 \mathrm{~mL}$ of dichloromethane. After filtration through a pipette containing glass wool and $3 \mathrm{~cm}$ of Celite ${ }^{\circledR}$, the red solution was concentrated to dryness in vacuo to yield $33.2 \mathrm{mg}(84 \%)$ of the product as a red solid. ${ }^{1} \mathrm{H}$ NMR $\left(250.13 \mathrm{MHz}, \mathrm{CDCl}_{3}\right) \delta 1.38$ $(\mathrm{s}, 18 \mathrm{H}, t-\mathrm{Bu}), 7.19\left(\mathrm{dd},{ }^{3} J_{\mathrm{HH}}=7.7 \mathrm{~Hz},{ }^{4} J_{\mathrm{HH}}=1.9 \mathrm{~Hz}, 2 \mathrm{H}\right.$, $3-\mathrm{H}, 9-\mathrm{H}), 7.65\left(\mathrm{dd},{ }^{4} J_{\mathrm{HH}}=1.9 \mathrm{~Hz},{ }^{5} J_{\mathrm{HH}}=1.0 \mathrm{~Hz}, 2 \mathrm{H}, 1-\mathrm{H}\right.$, $11-\mathrm{H}), 8.73\left(\mathrm{dd},{ }^{3} J_{\mathrm{HH}}=7.7 \mathrm{~Hz},{ }^{5} J_{\mathrm{HH}}=1.0 \mathrm{~Hz}, 2 \mathrm{H}, 4-\mathrm{H}, 8-\mathrm{H}\right)$; ${ }^{13} \mathrm{C}\left\{{ }^{1} \mathrm{H}\right\}$ NMR $\left(62.9 \mathrm{MHz}, \mathrm{CDCl}_{3}\right) \delta 30.2\left(\mathrm{C}\left(\mathrm{CH}_{3}\right)_{3}\right), 34.8$ $\left(\mathrm{C}\left(\mathrm{CH}_{3}\right)_{3}\right), 111.0(\mathrm{C} 1, \mathrm{C} 11), 116.2(\mathrm{C} 3, \mathrm{C} 9), 120.6(\mathrm{C} 11 \mathrm{a}$, C11b), 124.2 (C4, C8), 131.9 (C6), 142.6 (C2, C10); ${ }^{77} \mathrm{Se}$ NMR $\left(47.70 \mathrm{MHz}, \mathrm{CDCl}_{3}\right) \delta-55.8(\mathrm{~s}, \mathrm{Se})$; HRMS $\left(\mathrm{ESI}^{+}\right) \mathrm{m} / z$ : $360.11023\left[\mathrm{M}^{+}\right]$(calcd 360.10992).

\section{Supporting Information}

\section{Supporting Information File 1}

NMR spectra of compounds $\mathbf{2 a}, \mathbf{2} \mathbf{b}$ and $\mathbf{4 b}$ as well as details of the DFT calculations.

[http://www.beilstein-journals.org/bjoc/content/

supplementary/1860-5397-12-178-S1.pdf]

\section{Acknowledgements}

Financial help from the Deutsche Forschungsgemeinschaft (Emmy Noether-Programm (Ku 1437/2-3); Graduiertenkolleg 850 fellowship for M.N.) is gratefully acknowledged. We are thankful for continuous and generous support from Professor Peter Hofmann and we thank Professor Reinhold Fink for helpful discussions.

\section{References}

1. Öfele, K.; Herrmann, W. A.; Mihalios, D.; Elison, M.; Herdtweck, E.; Scherer, W.; Mink, J. J. Organomet. Chem. 1993, 459, 177. doi:10.1016/0022-328X(93)86070-X

2. Boehme, C.; Frenking, G. Organometallics 1998, 17, 5801. doi:10.1021/om980394r

3. Tafipolsky, M.; Scherer, W.; Öfele, K.; Artus, G.; Pedersen, B.; Herrmann, W. A.; McGrady, S. G. J. Am. Chem. Soc. 2002, 124, 5865. doi:10.1021/ja011761k

4. Hu, X.; Tang, Y.; Gantzel, P.; Meyer, K. Organometallics 2003, 22, 612-614. doi:10.1021/om020935j

5. Hu, X.; Castro-Rodrigues, I.; Olsen, K.; Meyer, K. Organometallics 2004, 23, 755-764. doi:10.1021/om0341855

6. Nemcsok, D.; Wichmann, K.; Frenking, G. Organometallics 2004, 23, 3640-3646. doi:10.1021/om049802j

7. Hahn, F. E.; Jahnke, M. C. Angew. Chem., Int. Ed. 2008, 47, 3122-3172. doi:10.1002/anie.200703883

8. Benhamou, L.; Chardon, E.; Lavigne, G.; Bellemin-Laponnaz, S.; César, V. Chem. Rev. 2011, 111, 2705-2733. doi:10.1021/cr100328e 
9. Mayr, M.; Wurst, K.; Ongania, K.-H.; Buchmeiser, M. R. Chem. - Eur. J. 2004, 10, 1256-1266. doi:10.1002/chem.200305437

10. Bazinet, P.; Yap, G. P. A.; Richeson, D. S. J. Am. Chem. Soc. 2003, 125, 13314-13315. doi:10.1021/ja0372661

11. Iglesias, M.; Beetstra, D. J.; Knight, J. C.; Ooi, L.-L.; Stasch, A.; Coles, S.; Male, L.; Hursthouse, M. B.; Cavell, K. J.; Dervisi, A.; Fallis, I. A. Organometallics 2008, 27, 3279-3289. doi:10.1021/om800179t

12. Iglesias, M.; Beetstra, D. J.; Stasch, A.; Horton, P. N.; Hursthouse, M. B.; Coles, S. J.; Cavell, K. J.; Dervisi, A.; Fallis, I. A. Organometallics 2007, 26, 4800-4809. doi:10.1021/om7004904

13. Scarborough, C. C.; Guzei, I. A.; Stahl, S. S. Dalton Trans. 2009, 2284-2286. doi:10.1039/b902460c

14. Khramov, D. M.; Rosen, E. L.; Lynch, V. M.; Bielawski, C. W. Angew. Chem., Int. Ed. 2008, 47, 2267-2270. doi:10.1002/anie.200704978

15. Siemeling, U.; Färber, C.; Bruhn, C. Chem. Commun. 2009, 98-100 doi:10.1039/B813809E

16. Lavallo, V.; Canac, Y.; Präsang, C.; Donnadieu, B.; Bertrand, G. Angew. Chem., Int. Ed. 2005, 44, 5705-5709. doi:10.1002/anie.200501841

17. Soleilhavoup, M.; Bertrand, G. Acc. Chem. Res. 2015, 48, 256-266. doi:10.1021/ar5003494

18. Hudnall, T. W.; Bielawski, C. W. J. Am. Chem. Soc. 2009, 131, 16039-16041. doi:10.1021/ja907481w

19. Braun, M.; Frank, W.; Reiss, G. J.; Ganter, G. Organometallics 2010, 29, 4418-4420. doi:10.1021/om100728n

20. César, V.; Lugan, N.; Lavigne, G. J. Am. Chem. Soc. 2008, 130, 11286-11287. doi:10.1021/ja804296t

21. Cavallo, L.; Correa, A.; Costabile, C.; Jacobsen, $H$. J. Organomet. Chem. 2005, 690, 5407-5413. doi:10.1016/j.jorganchem.2005.07.012

22. Jacobsen, H.; Correa, A.; Costabile, C.; Cavallo, L. J. Organomet. Chem. 2006, 691, 4350-4358. doi:10.1016/j.jorganchem.2006.01.026

23. Jacobsen, H.; Correa, A.; Poater, A.; Costabile, C.; Cavallo, L. Coord. Chem. Rev. 2009, 253, 687-703. doi:10.1016/j.ccr.2008.06.006

24. Huynh, H. V.; Frison, G. J. Org. Chem. 2013, 78, 328-338. doi:10.1021/jo302080c

25. Tolman, C. A. Chem. Rev. 1977, 77, 313-348. doi:10.1021/cr60307a002

26. Chianese, A. R.; Li, X.; Janzen, M. C.; Faller, J. W.; Crabtree, R. H. Organometallics 2003, 22, 1663-1667. doi:10.1021/om021029+

27. Wolf, S.; Plenio, H. J. Organomet. Chem. 2009, 694, 1487-1492. doi:10.1016/j.jorganchem.2008.12.047

28. Dorta, R.; Stevens, E. D.; Scott, N. M.; Costabile, C.; Cavallo, L.; Hoff, C. D.; Nolan, S. P. J. Am. Chem. Soc. 2005, 127, 2485-2495. doi:10.1021/ja0438821

29. Huynh, H. V.; Han, Y.; Jothibasu, R.; Yang, J. A. Organometallics 2009, 28, 5395-5404. doi:10.1021/om900667d

30. Teng, Q.; Huynh, H. V. Inorg. Chem. 2014, 53, 10964-10973. doi:10.1021/ic501325j

31. Lever, A. B. P. Inorg. Chem. 1990, 29, 1271-1285. doi:10.1021/ic00331a030

32. Koizumi, T.-a.; Tomon, T.; Tanaka, K. Organometallics 2003, 22, 970-975. doi:10.1021/om020637m

33. Ghattas, W.; Müller-Bunz, H.; Albrecht, M. Organometallics 2010, 29 , 6782-6789. doi:10.1021/om100925j
34. Dröge, T.; Glorius, F. Angew. Chem., Int. Ed. 2010, 49, 6940-6952. doi:10.1002/anie.201001865

35. Nelson, D. J.; Nolan, S. P. Chem. Soc. Rev. 2013, 42, 6723-6753. doi:10.1039/c3cs60146c

36. Setiawan, D.; Kalescky, R.; Kraka, E.; Cremer, D. Inorg. Chem. 2016, 55, 2332-2344. doi:10.1021/acs.inorgchem.5b02711

37. Bent, H. A. Chem. Rev. 1961, 61, 275-311. doi:10.1021/cr60211a005

38. Muller, N.; Pritchard, D. E. J. Chem. Phys. 1959, 31, 768-771. doi:10.1063/1.1730460

39. Weiss, R.; Reichel, S.; Handke, M.; Hampel, F. Angew. Chem., Int. Ed. 1998, 37, 344-346. doi:10.1002/(SICI)1521-3773(19980216)37:3<344::AID-ANIE344>3.0 $\mathrm{CO} ; 2-\mathrm{H}$

40. Bourissou, D.; Guerret, O.; Gabbaï, F. P.; Bertrand, G. Chem. Rev. 2000, 100, 39-91. doi:10.1021/cr940472u

41. Nonnenmacher, M.; Kunz, D.; Rominger, F.; Oeser, T. Chem. Commun. 2006, 1378-1380. doi:10.1039/b517816a

42. Liske, A.; Verlinden, K.; Buhl, H.; Schaper, K.; Ganter, C. Organometallics 2013, 32, 5269-5272. doi:10.1021/om400858y

43. Vummaleti, S. V. C.; Nelson, D. J.; Poater, A.; Gómez-Suárez, A.; Cordes, D. B.; Slawin, A. M. Z.; Nolan, S. P.; Cavallo, L. Chem. Sci. 2015, 6, 1895-1904. doi:10.1039/C4SC03264K

44. Verlinden, K.; Buhl, H.; Frank, W.; Ganter, C. Eur. J. Inorg. Chem. 2015, 2416-2425. doi:10.1002/ejic.201500174

45. Back, O.; Henry-Ellinger, M.; Martin, C. D.; Martin, D.; Bertrand, G. Angew. Chem., Int. Ed. 2013, 52, 2939-2943. doi:10.1002/anie.201209109

46. Rodrigues, R. R.; Dorsey, C. L.; Arceneaux, C. A.; Hudnall, T. W. Chem. Commun. 2014, 50, 162-164. doi:10.1039/C3CC45134H

47. Weiss, R.; Reichel, S. Eur. J. Inorg. Chem. 2000, 1935-1939. doi:10.1002/1099-0682(200009)2000:9<1935::AID-EJIC1935>3.0.CO; 2-U

48. Reichel, S. Ph.D. Thesis, Universität Erlangen-Nürnberg, 1998.

49. Ramirez, F.; Desai, N. B.; Hansen, B.; McKelvie, N. J. Am. Chem. Soc. 1961, 83, 3539-3540. doi:10.1021/ja01477a052

50. Dyker, C. A.; Lavallo, V.; Donnadieu, B.; Bertrand, G. Angew. Chem., Int. Ed. 2008, 47, 3206-3209. doi:10.1002/anie.200705620

51. Fürstner, A.; Alcarazo, M.; Goddard, R.; Lehmann, C. W. Angew. Chem., Int. Ed. 2008, 47, 3210-3214. doi:10.1002/anie.200705798

52. Schmidbaur, H. Angew. Chem., Int. Ed. Engl. 1983, 22, 907-927. doi:10.1002/anie.198309071

53. Tonner, R.; Frenking, G. Angew. Chem., Int. Ed. 2007, 46, 8695-8698. doi:10.1002/anie.200701632

54. Guha, A. K.; Phukan, A. K. Chem. - Eur. J. 2012, 18, 4419-4425. doi:10.1002/chem.201103250

55. Nonnenmacher, M.; Kunz, D.; Rominger, F.; Oeser, T. J. Organomet. Chem. 2005, 690, 5647-5653. doi:10.1016/j.jorganchem.2005.07.033

56. Nonnenmacher, M.; Rominger, F.; Kunz, D. Organometallics 2008, 27, 1561-1568. doi:10.1021/om701196c

57. Brill, M.; Marrwitz (née Eisenhauer), D.; Rominger, F.; Hofmann, P. J. Organomet. Chem. 2015, 775, 137-151. doi:10.1016/j.jorganchem.2014.04.008

58. Canepa, G.; Brandt, C. D.; Werner, H. Organometallics 2004, 23, 1140-1152. doi:10.1021/om034348p

59. Chaplin, A. B.; Weller, A. S. Organometallics 2010, 29, 2332-2342. doi:10.1021/om100105p 
60. Fu, C.-F.; Chang, Y.-H.; Liu, Y.-H.; Peng, S.-M.; Elsevier, C. J.; Chen, J.-T.; Liu, S.-T. Dalton Trans. 2009, 6991-6998. doi:10.1039/b906016b

61. Buhl, H.; Ganter, C. J. Organomet. Chem. 2016, 809, 74-78. doi:10.1016/j.jorganchem.2016.02.034

62. Neveling, A.; Julius, G. R.; Cronje, S.; Esterhuysen, C.; Raubenheimer, H. G. Dalton Trans. 2005, 181-192. doi:10.1039/b414040k

63. Bittermann, A.; Herdtweck, E.; Härter, P.; Herrmann, W. A. Organometallics 2009, 28, 6963-6968. doi:10.1021/om900785p

64. Bittermann, A.; Härter, P.; Herdtweck, E.; Hoffmann, S. D.; Herrmann, W. A. J. Organomet. Chem. 2008, 693, 2079-2090. doi:10.1016/j.jorganchem.2008.01.039

65. Sanderson, M. D.; Kamplain, J. W.; Bielawski, C. W. J. Am. Chem. Soc. 2006, 128, 16514-16515. doi:10.1021/ja067475w

66. Katakis, D.; Gordon, G. Mechanisms of Inorganic Reactions; John Wiley \& Sons: New York, NY, U.S.A., 1987.

67. Basolo, F.; Pearson, R. G. Mechanismen in der anorganischen Chemie. Thieme: Stuttgart, Germany, 1973.

68. Crozet, D.; Gual, A.; McKay, D.; Dinoi, C.; Godard, C.; Urrutigoïty, M.; Daran, J.-C.; Maron, L.; Claver, C.; Kalck, P. Chem. - Eur. J. 2012, 18, 7128-7140. doi:10.1002/chem.201103474

69. Alcarazo, M.; Roseblade, S. J.; Cowley, A. R.; Fernández, R.; Brown, J. M.; Lassaletta, J. M. J. Am. Chem. Soc. 2006, 127 , 3290-3291. doi:10.1021/ja0423769

70. Enders, D.; Breuer, K.; Raabe, G.; Runsink, J.; Teles, J. H.; Melder, J.-P.; Ebel, K.; Brode, S. Angew. Chem., Int. Ed. Engl. 1995, 34, 1021-1023. doi:10.1002/anie.199510211

71. Martin, D.; Baceiredo, A.; Gornitzka, H.; Schoeller, W. W.; Bertrand, G. Angew. Chem., Int. Ed. 2005, 44, 1700-1703. doi:10.1002/anie.200462239

72. Arduengo, A. J., III; Dias, H. V. R.; Harlow, R. L.; Kline, M. J. Am. Chem. Soc. 1992, 114, 5530-5534. doi:10.1021/ja00040a007

73. Herrmann, W. A.; Elison, M.; Fischer, J.; Köcher, C.; Artus, G. R. J. Chem. - Eur. J. 1996, 2, 772-780. doi:10.1002/chem.19960020708

74. Arduengo, A. J., III; Goerlich, J. R.; Marshall, W. J. J. Am. Chem. Soc. 1995, 117, 11027-11028. doi:10.1021/ja00149a034

75. Denk, K.; Sirsch, P.; Herrmann, W. A. J. Organomet. Chem. 2002, 649, 219-224. doi:10.1016/S0022-328X(02)01133-6

76. Alder, R. W.; Allen, P. R.; Murray, M.; Orpen, A. G. Angew. Chem., Int. Ed. Engl. 1996, 35, 1121-1123. doi:10.1002/anie.199611211

77. Selenourea $\mathbf{4 a}$ was already prepared by Weiss and co-workers, see $[39,47]$, however, no ${ }^{77}$ Se NMR chemical shift was reported.

78. Reed, A. E.; Weinstock, R. B.; Weinhold, F. J. Chem. Phys. 1985, 83, 735-746. doi:10.1063/1.449486

79. Luy, J.-N.; Hauser, S. A.; Chaplin, A. B.; Tonner, R. Organometallics 2015, 34, 5099-5112. doi:10.1021/acs.organomet.5b00692

80. Duddeck, H. Prog. Nucl. Magn. Reson. Spectrosc. 1995, 27, 1-323. doi:10.1016/0079-6565(94)00005-F

81. Becke, A. D. Phys. Rev. A 1988, 38, 3098-3100. doi:10.1103/PhysRevA.38.3098

82. Perdew, J. P. Phys. Rev. B 1986, 33, 8822-8824. doi:10.1103/PhysRevB.33.8822

83. Schäfer, A.; Horn, H.; Ahlrichs, R. J. Chem. Phys. 1992, 97, 2571-2577. doi:10.1063/1.463096

84. Weigend, F.; Ahlrichs, R. Phys. Chem. Chem. Phys. 2005, 7, 3297-3305. doi:10.1039/b508541a

85. Weigend, F. Phys. Chem. Chem. Phys. 2006, 8, 1057-1065. doi:10.1039/b515623h
86. Becke, A. D. J. Chem. Phys. 1993, 98, 5648-5652. doi:10.1063/1.464913

87. Lee, C.; Young, W.; Parr, R. G. Phys. Rev. B 1988, 37, 785-789. doi:10.1103/PhysRevB.37.785

88. Schäfer, A.; Huber, C.; Ahlrichs, R. J. Chem. Phys. 1994, 100, 5829-5835. doi:10.1063/1.467146

89. TURBOMOLE, V6.3.1; University of Karlsruhe and Forschungszentrum Karlsruhe GmbH, 1989-2007, TURBOMOLE $\mathrm{GmbH}$, since 2007: Karlsruhe, Germany, 2011, http://www.turbomole.com.

90. Treutler, O.; Ahlrichs, R. J. Chem. Phys. 1995, 102, 346-354. doi:10.1063/1.469408

91. von Arnim, M.; Ahlrichs, R. J. Comput. Chem. 1998, 19, 1746-1757. doi:10.1002/(SICI)1096-987X(19981130)19:15<1746::AID-JCC7>3.0. $\mathrm{CO} ; 2-\mathrm{N}$

92. van Wüllen, C. J. Comput. Chem. 2011, 32, 1195-1201. doi:10.1002/jcc.21692

93. Deglmann, P.; Furche, F.; Ahlrichs, R. Chem. Phys. Lett. 2002, 362, 511-518. doi:10.1016/S0009-2614(02)01084-9

94. Deglmann, P.; Furche, F. J. Chem. Phys. 2002, 117, 9535-9538. doi:10.1063/1.1523393

95. Ahlrichs, R.; Bär, M.; Häser, M.; Horn, H.; Kölmel, C. Chem. Phys. Lett. 1989, 162, 165-169. doi:10.1016/0009-2614(89)85118-8

96. Armbruster, M. K.; Weigend, F.; van Wüllen, C.; Klopper, W. Phys. Chem. Chem. Phys. 2008, 10, 1748-1756. doi:10.1039/b717719d

97. Peng, D.; Middendorf, N.; Weigend, F.; Reiher, M. J. Chem. Phys. 2013, 138, 184105. doi:10.1063/1.4803693

98. Eichkorn, K.; Treutler, O.; Öhm, H.; Häser, M.; Ahlrichs, R. Chem. Phys. Lett. 1995, 240, 283-290. doi:10.1016/0009-2614(95)00621-A

99. Eichkorn, K.; Treutler, O.; Öhm, H.; Häser, M.; Ahlrichs, R. Chem. Phys. Lett. 1995, 242, 652-660. doi:10.1016/0009-2614(95)00838-U

100. Eichkorn, K.; Weigend, F.; Treutler, O.; Ahlrichs, R. Theor. Chem. Acc. 1997, 97, 119-124. doi:10.1007/s002140050244

101.Deglmann, P.; May, K.; Furche, F.; Ahlrichs, R. Chem. Phys. Lett. 2004, 384, 103-107. doi:10.1016/j.cplett.2003.11.080

102. Weigend, F. Phys. Chem. Chem. Phys. 2002, 4, 4285-4291. doi:10.1039/b204199p

103.Sierka, M.; Hogekamp, A.; Ahlrichs, R. J. Chem. Phys. 2003, 118, 9136-9148. doi:10.1063/1.1567253

104.Andrae, D.; Häußermann, U.; Dolg, M.; Stoll, H.; Preuß, H. Theor. Chim. Acta 1990, 77, 123-141. doi:10.1007/BF01114537

105. Grimme, S.; Antony, J.; Ehrlich, S.; Krieg, H. J. Chem. Phys. 2010, 132, 154104. doi:10.1063/1.3382344

106. POV-RayTM for Windows, v3.6.2; Persistence of Vision Pty. Ltd.: Williamstown, Victoria, Australia, http://www.povray.org/. 


\section{License and Terms}

This is an Open Access article under the terms of the Creative Commons Attribution License

(http://creativecommons.org/licenses/by/4.0), which permits unrestricted use, distribution, and reproduction in any medium, provided the original work is properly cited.

The license is subject to the Beilstein Journal of Organic Chemistry terms and conditions:

(http://www.beilstein-journals.org/bjoc)

The definitive version of this article is the electronic one which can be found at:

doi:10.3762/bjoc. 12.178 